\title{
PENERAPAN METODE EKSPERIMEN BERBASIS KIT IPA DALAM UPAYA MENCAPAI KETUNTASAN HASIL BELAJAR SISWA PADA MATERI PESAWAT SEDERHANA KELAS V SDN 2 PURWASANA KECAMATAN PUNGGELAN KABUPATEN BANJARNEGARA
}

\author{
Misno \\ Pendidikan Dasar, Pascasarjana Universitas Negeri Surabaya \\ email: minnoz13@gmail.com
}

\begin{abstract}
Abstrak
Penelitian ini bertujuan untuk mendeskripsikan penerapan metode eksperimen berbasis KIT IPA dalam upaya meningkatkan hasil belajar siswa pada materi pesawat sederhana siswa kelas V SDN 2 Purwasana Kecamatan Punggelan Kabupaten Banjarnegara. Jenis penelitian ini adalah penelitian tindakan kelas yang dilaksanakan selama dua siklus pembelajaran. Tiap siklus pembelajaran terdiri atas (1) perencanaan (2) pelaksanaan (3) observasi dan (4) refleksi. Perangkat pembelajaran yang digunakan meliputi silabus, rencana pelaksanaan pembelajaran, lembar kerja siswa, buku siswa, dan lembar evaluasi. Instrumen yang digunakan dalam penelitian ini meliputi lembar pengamatan aktivitas guru dalam mengelola pembelajaran, lembar aktivitas siswa mengikuti pembelajaran, serta angket respon siswa terhadap pembelajaran. Kurikulum yang digunakan dalam penelitian ini adalah kurikulum tingkat satuan pendidikan (2006) dengan materi pokok energi dan perubahannya sub materi pesawat sederhana.

Adapun data yang dianalisis sebagai hasil penelitian meliputi: (1) hasil belajar siswa, (2) aktivitas guru dalam mengelola pembelajaran, (3) aktivitas siswa dalam mengikuti pembelajaran, (4) respon siswa terhadap pembelajaran yang diikutinya.

Dari hasil analisis diperoleh: (1) hasil belajar ranah kognitif dengan rata- rata kelas 78,52 dengan kategori "tuntas" dan ketuntasan klasikal mencapai 89\% dengan kategori "tuntas", (2) aktivitas guru dalam mengelola pembelajaran mencapai persentase ketercapaian $86,17 \%$ berada dalam kategori "sangat baik", (3) aktivitas siswa dalam mengikuti pembelajaran mencapai kategori "efektif", (4) respon siswa terhadap pembelajaran mencapai kategori "positif" yaitu senang, baru, berminat, dan jelas. Berdasarkan pembahasan hasil penelitian dan analisis data dapat disimpulkan bahwa terdapat peningkatan hasil belajar siswa dengan penerapan metode eksperimen berbasis KIT IPA.
\end{abstract}

Kata Kunci: Metode ekspermen berbasis KIT IPA, hasil belajar

\begin{abstract}
This study aimed to describe the application of the experimental method based KIT IPA in an effort to improve student learning outcomes in a simple macine material fifth grade students of SDN 2 Purwasana the District Punggelan

Banjarnegara. This research is a classroom action research carried out during two cycles of learning. Each learning cycle consists of (1) planning (2) the implementation of (3) observation and (4) reflection. Learning tools used include syllabi, lesson plan, student worksheet, student books, and evaluation sheets. The instrument used in this study include the observation sheet teachers in managing the learning activity, students follow a learning activity sheets, as well as the student questionnaire responses to learning. The curriculum used in this study is the education unit level curriculum 2006 with the subject matter of energy and materials sub material simple machine.

The data were analyzed as a result of research include: (1) the results of student learning, (2) the activity of teachers in managing learning, (3) the activity of students in the following study, (4) students' response to learning that followed.

The results of analysis: (1) cognitive learning outcomes with an average grade 78.52 with categories "complete" and the classical completeness reach $89 \%$ by the category of "complete", (2) the activity of teachers in managing the learning achievement of reaching the percentage of $86,17 \%$ are in the category of "very good", (3) the activity of students in the following study reached the category of "effective", (4) the response of students to achieve the learning category of "positive" that is happy, new, interested and clear. Based on the discussion of the results of research and data analysis can be concluded that there is an increase in student learning outcomes with the application of the experimental method based KIT IPA.
\end{abstract}

Keywords: experimental method based KIT IPA, learning outcomes 


\section{PENDAHULUAN}

Pembelajaran IPA berhubungan dengan cara mencari tahu. IPA bukan hanya penguasaan kemampuan pengetahuan yang berupa fakta, konsep, atau prinsip tetapi merupakan suatu proses penemuan. Pendidikan IPA diarahkan untuk menemukan dan berbuat sehingga dapat membantu siswa untuk memperoleh pemahaman yang lebih mendalam.

Proses pembelajaran akan dapat berjalan dengan baik dan respon siswa akan muncul jika terjadi dalam situasi yang menyenangkan bagi siswa. Proses pembelajaran akan berjalan dengan baik jika ada dorongan dan kebutuhan yang jelas dari pihak guru maupun siswa yang dioperasionalkan dalam tujuan pembelajaran. Tujuan pembelajaran harus dapat diukur, sehingga perubahan perilaku siswa dapat jelas terlihat sebagai akibat dari proses pembelajaran (Winataputra, 2013). Dalam proses pembelajaran terdapat serangkaian kegiatan untuk memberikan pengalaman belajar yang berkaitan dengan pengetahuan, keterampilan, dan sikap.

Ada dua aspek penting dalam pembelajaran, yang pertama aspek hasil belajar, yaitu perubahan tingkah laku siswa, dan yang kedua aspek proses belajar, yaitu sejumlah pengalaman intelektual, emosional, dan keterampilan fisik pada diri siswa. Joyce, Weil, dan Calhoun (2011:6-7) mengemukakan bahwa pembelajaran yang baik adalah pembelajaran yang merangkul pengalaman belajar tanpa batas tentang bagaimana gagasan dan emosi berinteraksi dengan suasana kelas dan bagaimana keduanya dapat berubah sesuai dengan suasana kelas yang juga terus berubah. Cara guru menerapkan suatu pembelajaran akan berpengaruh besar terhadap kemampuan siswa dalam mendapatkan pengetahuan.

Pembelajaran akan lebih menarik dan siswa akan sangat antusias apabila dalam pelaksanaannya menggunakan alat peraga. Beberapa ahli pendidikan telah mendefinisikan tentang alat peraga. Menurut Trisnoherawati (2014:1) "Alat peraga IPA merupakan alat-alat yang digunakan untuk prcobaan dalam pembelajaran IPA di kelas Sekolah Dasar". Penggunaan alat peraga mampu memvisualisasikan materi pembelajaran dari abstrak ke konkret, dari sukar ke mudah, dan dari rumit ke sederhana. Penggunaan alat peraga juga memiliki peranan dalam memberikan pengalaman langsung pada siswa. Pernyataan tersebut sesuai dengan pendapat dari Piaget dalam Samatowa, (2006:12) yang menyatakan bahwa pengalaman langsung yang memegang peranan penting sebagai pendorong lajunya perkembangan kognitif siswa. Melalui pengalaman yang diperoleh secara langsung siswa akan mengalami sendiri, berbuat sendiri, sehingga hasilnya akan lebih berarti bagi siswa, Sudjana (1989:107). Alat peraga yang dimaksud adalah KIT IPA. KIT IPA merupakan alat yang digunakan untuk membantu kegiatan pembelajaran dalam mencapai tujuan pembelajaran IPA yang telah ditentukan melalui percobaan dengan memanfaatkan bahan yang sederhana.

Namun kenyataan di lapangan, pembelajaran IPA masih belum maksimal sehingga berpengaruh pada rendahnya hasil belajar. Interaksi guru dan murid sekedar transfer pengetahuan dari seorang guru terhadap murid. Metode pembelajaran dengan menempatkan guru sebagai satu satunya sumber pengetahuan dan siswa hanya diberi ceramah untuk mendapatkan pengetahuannya. Siswa hanya diminta menghafal tanpa tau bagaimana konsep ilmu pengetahuan diperoleh. Dalam proses pembelajaran, guru berperan dominan dan informasi hanya berjalan satu arah dari guru ke siswa, sehingga siswa sangat pasif.

Pada saat observasi, peneliti menemukan hasil belajar siswa kelas V SDN 2 Purwasana pada mata pelajaran IPA khususnya KD 5.2 tentang Pesawat Sederhana masih rendah. Hal itu dibuktikan dengan nilai yang diperoleh siswa, dari 27 siswa hanya 8 siswa atau 30\% yang mencapai KKM sedangkan sebanyak 19 siswa atau $70 \%$ belum mencapai KKM yang ditetapkan.

Rendahnya hasil belajar tersebut disebabkan oleh beberapa faktor yaitu; 1) dalam proses pembelajaran masih berpusat pada guru (teacher center), sehingga siswa terlihat bosan dalam menerima pembelajaran, 2) metode pembelajaran tanpa menghadirkan benda-benda nyata sehingga membuat siswa kurang memahami konsep yang dipelajari, 3) penggalian materi terbatas pada satu sumber, hal tersebut tampak dari kurangnya penggalian materi dari kehidupan seharihari siswanya; 4) kegiatan siswa hanya terbatas pada menyimak dan mengerjakan soal tanpa adanya pertanyaan ataupun kreasi dari siswa sendiri; 5) pengelolaan siswa masih monoton, yakni diskusi tanpa pelaporan secara lisan atau hanya laporan dalam bentuk tulisan saja. 
Bertolak dari beberapa masalah di atas, masalah yang harus segera mendapat perhatian agar hasil belajar siswa dapat ditingkatkan secara maksimal terutama tentang metode pembelajaran. Metode yang dimaksud adalah metode pembelajaran yang mengarahkan aktivitas siswa dan mendekatkan siswa dengan dunia nyata.

Metode yang sesuai dengan kriteria di atas adalah metode eksperimen. Metode eksperimen merupakan metode dalam pembelajaran yang mengajak siswa untuk melakukan percobaan terkait dengan materi yang dipelajari. Siswa berhadapan langsung dengan benda-benda yang dipelajari, sehingga siswa dapat menggali pengetahuannya sendiri dengan melakukan percobaan. Hasil belajar siswa dengan menerapkan model pengajaran langsung dengan metode eksperimen lebih baik daripada penerapan metode konvensional, Suliyanah (2014). Metode eksperimen menerapkan nilai-nilai atau sifat-sifat ilmiah dan menghindari nilai- nilai atau sifat-sifat non ilmiah. Metode eksperimen memiliki karakteristik: 1) berpusat pada siswa, 2) melibatkan keterampilan proses sains dalam mengonstruksi konsep, hukum atau prinsip, 3) melibatkan proses-proses kognitif yang potensial dalam merangsang perkembangan intelektual, khususnya keterampilan berpikir tingkat tinggi siswa, 4) dapat mengembangkan karakter siswa. Hasil penelitian menunjukkan bahwa pengajaran pokok bahasan pesawat sederhana dengan metode eksperimen dapat meningkatkan hasil belajar siswa, Muna (2014).

Berdasarkan uraian pendahuluan tersebut, maka rumusan masalah dalam penelitian ini adalah "bagaimana ketuntasan hasil belajar siswa pada materi pesawat sederhana dengan penerapan metode eksperimen berbasis KIT IPA di kelas V SDN 2 Purwasana?"

\section{METODE PENELITIAN}

Penelitian ini merupakan penelitian tindakan kelas yang difokuskan pada situasi kelas yang lazim disebut classroom action research. Rancangan atau desain penelitian ini menggunakan model Kemmis S. \& Mc. Taggart, (2007:141). Dalam rancangan tersebut terdiri dari beberapa siklus. Setiap siklus dalam penelitian ini terdiri dari empat tahapan yaitu; (1) tahap perencanaan, (2) tahap tindakan, (3) tahap observasi, dan (4) tahap refleksi. Jumlah siklus yang dilakukan disesuaikan dengan tingkat pencapaian tujuan. Maksudnya, apabila tujuan telah tercapai setelah diberi perlakuan maka siklus dihentikan dan penelitian dianggap selesai. Tujuan dikatakan tercapai apabila terjadi peningkatan hasil belajar siswa pada materi yang disampaikan dalam penelitian.

Data dalam penelitian ini diperoleh menggunakan teknik 1) Observasi 2) Tes Hasil Belajar 3) Penyebaran Angket Respon Siswa Terhadap Kegiatan Pembelajaran. Analisis data yang digunakan adalah analisis data kualitatif melalui observasi dan analisis data kuantiatif melalui tes tertulis yaitu menjawab soalsoal yang menyangkut materi pembelajaran yang diberikan. Kegiatan analisis data dimulai dengan menelaah seluruh data yang terkumpul dari hasil pengamatan dan hasil tes belajar siswa, hasil analisis data kemudian disajika dalam bentuk deskriptif kualitatif.

\section{HASIL DAN PEMBAHASAN}

Hasil penelitian siklus I diketahui bahwa dari 27 siswa kelas V, siswa yang berhasil mencapai ketuntasan sebanyak 17 siswa, dan 10 siswa belum tuntas. Persentase ketuntasan pada siklus 1 mencapai $63 \%$ terdapat kenaikan 33\% dari temuan awal. Akan tetapi hasil tersebut belum mencapai persentase ketuntasan klasikal yang ditetapkan yaitu $\geq 80 \%$, sehingga perlu adanya tindak lanjut dengan pelaksanaan siklus lanjutan.

Penilaian hasil belajar siswa ranah sikap siklus I terlihat bahwa nilai rata- rata kelas pada tes akhir siklus I sebesar 71,42 dan termasuk kriteria cukup, sedangkan KKM yang ditetapkan sekolah adalah 70 dan ketuntasan belajar baru mencapai 59\% yaitu 16 siswa yang tuntas, dan $41 \%$ atau 11 siswa belum tuntas. Hal ini masih belum mencapai target yang diharapkan maka perlu direncanakan untuk melakukan perbaikan pada siklus II.

Penilaian hasil belajar ranah psikomotor pada siklus I, nilai rata-rata kelas sebesar 67,31 , nilai ini belum mencapai KKM yang diterapkan yiatu $\geq 70$. Sedangkan dalam persentase hanya $51 \%$ siswa yang aktif dalam proses pembelajaran atau 14 siswa yang tuntas dalam pembelajaran, dan 13 siswa atau

49\% lagi tidak tuntas, sehingga perlu ditingkatkan pada siklus berikutnya.

Hasil observasi aktivitas guru, pada kegiatan pendahuluan rata-rata memeroleh skor $75 \%$ atau kategori "sangat baik". Aspek aktivitas guru pada kegiatan inti memeroleh skor 77,5 atau berada 
pada kategori "baik". Aspek aktivitas guru kegiatan penutup memeroleh skor $75 \%$ atau berada pada kategori "baik". Aspek aktivitas guru ditinjau dari efisiensi penggunaan waktu memeroleh skor $62,5 \%$ atau berada pada kategori "cukup". Sedangkan aktivitas guru dalam menciptakan suasana kelas memeroleh skor $75 \%$ atau berada pada kategori "baik".

Data respon siswa pada pelaksanaan pembelajaran metode eksperimen berbasis KIT IPA berada pada kategori "sangat baik". Aspek minat siswa terhadap materi energi dan perubahannya submateri pesawat sederhana ada $74 \%$ siswa menyatakan "senang", $19 \%$ menyatakan "tidak senang", dan 7\% menyatakan "tidak berpendapat". Sedangkan dari aspek baru $74 \%$ siswa menyatakan materi energi dan perubahannya adalah "baru" dan $15 \%$ siswa menyatakan "tidak baru", serta $11 \%$ menyatakan "tidak berependapat". Aspek minat siswa tentang LKS ada $82 \%$ menyatakan "senang", $11 \%$ menyatakan "tidak senang", dan 7\% menyatakan "tidak berpendapat". Sedangkan untuk aspek kebaruan 74\% siswa menyatakan bahwa bentuk LKS adalah "baru", $15 \%$ menyatakan "tidak baru", dan $11 \%$ menyatakan "tidak berpendapat". Aspek buku ada $82 \%$ siswa menyatakan " senang”, $18 \%$ siswa menyatakan "tidak senang", dan $0 \%$ menyatakan "tidak berpendapat". Sedangkan dari aspek kebaruan $78 \%$ siswa menyatakan "baru", dan $15 \%$ menyatakan "tidak baru" serta 7\% tidak berpendapat. Aspek suasana belajar ada $78 \%$ siswa menyatakan 'baru", $11 \%$ siswa menyatakan "tidak baru", dan $11 \%$ siswa menyatakan "tidak berpendapat". Aspek kebaruan ada 89\% siswa menyatakan "baru", $0 \%$ siswa menyatakan "tidak baru", dan $11 \%$ siswa menyatakan "tidak berpendapat". Minat siswa pada aspek penampilan guru ada $82 \%$ siswa menyatakan "senang", dan $18 \%$ siswa menyatakan "tidak senang", dan $0 \%$ menyatakan "tidak berependapat". Dari aspek kebaruan $89 \%$ siswa menyatakan "baru", $7 \%$ siswa menyatakan "tdak baru", dan $4 \%$ siswa menyatakan "tidak berpendapat". Minat siswa pada aspek cara guru mengajar $85 \%$ siswa menyatakan "senang", $15 \%$ siswa menyatakan "tidak senang",dan $0 \%$ menyatakan "tidak berpendapat". Dari aspek kebaruan 89\% siswa menyatakan "baru", 0\% siswa menyatakan "tidak baru", dan $11 \%$ persen siswa menyatakan "tidak berpendapat". Untuk aspek minat siswa untuk mengikuti pembelajaran metode eksperimen berbasis KIT IPA pada pertemuan berikutnya adalah 93\% menyatakan "berminat", dan 7\% menyatkan "tidak tahu". Sedangkan aspek keterbacaan LKS 78\% siswa menyatakan "jelas", dan $22 \%$ menyatakan "tidak jelas".

SIKLUS 2

Penilaian hasil belajar ranah kognitif pada siklus II dapat diketahui bahwa dari 27 siswa kelas V, siswa yang berhasil mencapai ketuntasan sebanyak 24 siswa, hal ini berarti bahwa terdapat 3 siswa yang belum tuntas. Persentase ketuntasan klasikal pada siklus II mencapai $89 \%$, terdapat kenaikan $36 \%$ dari ketuntasan klasikal pada siklus I. Hal ini berarti pelaksanaan pembelajaran metode eksperimen berbasis KIT IPA telah mencapai persentase ketuntasan klasikal yang ditetapkan yaitu $\geq 80 \%$.

Pengaruh pembelajaran metode eksperimen berbasis KIT IPA pada ranah kognitif siklus II menunjukan perbedaan sekaligus adanya peningkatan yang signifikan pengetahuan IPA siswa sebelum dan sesudah perlakuan. Pada tes hasil belajar siswa ranah kognitif siklus II dikategorikan sebagai g-tinggi dengan rata- rata gain sebesar 0.7 atau $70 \%$. Hal ini menunjukan bahwa terjadi peningkatan pemahaman materi pesawat sederhana melalui kegiatan pembelajaran metode eksperimen berbasis KIT IPA pada siklus II ( Borich dalam Ibrahim, 2005).

Penilaian hasil belajar ranah sikap pada siklus II menunjukkan bahwa nilai rata-rata kelas sebesar 77,22. Sedangkan nilai KKM yang ditentukan sebesar 70, persentase yang diperoleh $77 \%$ hal ini membuktikan telah terjadi peningkatan dari siklus sebelumnya. Dan persentase perorangan juga sudah meningkat yaitu sudah mencapai $85,19 \%$ atau 23 orang sudah aktif dalam pembelajaran, dan $14,81 \%$ tidak tuntas atau 4 siswa , untuk 4 siswa ini akan dilakukan remedial.

Penilaian hasil belajar ranah psikomotor pada siklus II nilai rata-rata kelas sebesar 75,12, dan persentase ketuntasan $88,89 \%$ yang diperoleh pada siklus II ini sudah membuktikan bahwa penerapan metode eksperimen berbasis KIT IPA sudah mengalami perubahan dari siklus sebelumnya. Sehingga proses pembelajaran sudah berjalan sesuai dengan yang diharapkan.

Data aktivitas guru dalam mengelola pembelajaran pada siklus II menunjukkan bahwa aktivitas guru dalam pembelajaran metode eksperimen berbasis KIT IPA mencapai angka 
$86,17 \%$. Persentase pencapaian tersebut telah memenuhi target. Hal ini berarti aktivitas guru telah tuntas atau berada pada kategori "sangat baik".

Data aktivitas siswa dalam pembelajaran mengalami peningkatan. Aspek mendengarkan/ memerhatikan penjelasan guru mencapai persentase $74,07 \%$ berada pada kategori baik . Aspek mngerjakan LKS mencapai persentase 76,39\% berada pada kategori baik. Aspek mempraktikan langkah-langkah eksperimen mencapi persentase $78,70 \%$ berada pada kategori baik. Aspek bertanya jawab/ diskusi dengan teman berada pada kategori baik dengan persentase mencapai $78,70 \%$, Aspek bertanya kepada guru mencapai $80,09 \%$ berada pada kategori sangat baik. Aspek membuat rangkuman materi pembelajaran berada pada kategori sangat baik dengan persentase 82,41\%. Aspek mempresentasikan hasil kerja kelompok juga berada pada kategori baik dengan prosentase $79,63 \%$, dan aspek menyimpulkan pelajaran berada pada persentase $81,94 \%$ dengan kategori sangat baik.

Data Respon Siswa dalam Pembelajan siklus II secara umum berada pada kategori sangat baik, dan secara rinci akan dijabarkan sebagai berikut: Aspek minat siswa terhadap materi gaya ada $89 \%$ siswa menyatakan "senang", $7 \%$ menyatakan tidak senang, dan $4 \%$ tidak berpendapat, sedangkan dari aspek kebaruan, $85 \%$ siswa menyatakan bahwa materi gaya adalah "baru" dan $0 \%$ siswa menyatakan"tidak baru", dan $15 \%$ tidak berpendapat. Aspek minat siswa tentang LKS ada $89 \%$ menyatakan "senang", $4 \%$ menyatakan"tidak senang”, dan $7 \%$ menyatakan "tidak berpendapat". Sedangkan untuk aspek kebaruan $89 \%$ siswa menyatakan bahwa LKS adalah "baru, 7\% menyatakan "tidak baru", dan 4\% tidak berpendapat. Aspek buku siswa ada $85 \%$ siswa menyatakan "senang", $15 \%$ siswa menyatakan "tidak senang", sedangkan dari aspek kebaruan $82 \%$ menyatakan "baru", dan $7 \%$ menyatakan "tidak baru", dan $11 \%$ tidak berpendapat. Aspek suasana belajar ada $89 \%$ siswa menyatakan "senang", $0 \%$ siswa menyatakan "tidak senang", dan $11 \%$ "tidak berpendapat”. Aspek kebaruan ada 93\% siswa menyatakan "baru", $0 \%$ siswa menyatakan "tidak baru", dan $7 \%$ siswa menyatakan 'tidak berpendapat". Minat siswa pada aspek penampilan guru ada siswa $89 \%$ siswa menyatakan "senang",
$0 \%$ siswa menyatakan "tidak senang", dan $11 \%$ siswa menyatakan "tidak berpendapat", dari aspek kebaruan $89 \%$ siswa menyatakan "baru", $7 \%$ siswa menyatakan "tidak baru", dan $4 \%$ siswa menyatakan "tidak berpendapat". Minat siswa pada aspek cara guru mengajar 96\% menyatakan "senang, $0 \%$ menyatakan "tidak senang", dan $4 \%$ menyatakan "tidak berpendapat", dalam aspek kebaruan $89 \%$ siswa menyatakan "baru", 7\% siswa menyatakan "tidak baru", dan $4 \%$ siswa menyatakan "tidak berpendapat". Untuk aspek minat siswa untuk mengikuti pembelajaran metode eksperimen berbasis KIT IPA pada pertemuan berikutnya adalah $100 \%$. Sedangkan aspek keterbacaan keterbacaan LKS 93\% menyatakan "jelas", 7\% mrnyatakan "tidak jelas" dan $0 \%$ tidak berpendapat.

\section{PENUTUP}

Berdasarkan hasil penelitian tindakan yaitu penerapan metode eksperimen berbasis KIT IPA untuk materi pokok energi dan peruhabannya submateri pesawat sederhana di kelas V SDN 2 Purwasana Kecamatan Punggelan Kabupaten Banjarnegara, dapat disimpulkan sebagai berikut:

1. Terdapat peningkatan hasil belajar kognitif siswa dari studi awal hingga siklus II. Nilai rata-rata kelas siklus I dari 75,31 naik menjadi 78,52 atau naik $3,19 \%$. Sementara ketuntasan klasikla naik dari $30 \%$ pada studi awal menjadi $63 \%$ pada siklus I dan siklus II meningkat menjadi $89 \%$ atau hanya $11 \%$ atau 3 siswa yang belum tuntas, hasil belajar siswa ranah sikap rata-rata kelas 77,22 , dan hasil belajar siswa ranah psikomotor dengan rata-rata kelas sebesar 75,12. Dengan demikian pembelajaran ini dinyatakan tuntas, karena sudah memenuhi kriteria yang ditentukan sesuai dengan indikator keberhasilan.

2. Terdapat peningkatan aktivitas guru sebesar $11,17 \%$ dari siklus I sebesar $75 \%$ yang berarti termasuk pada kategori "baik" menjadi $86,17 \%$ yang berarti termasuk pada kategori "sangat baik" pada siklus II.

3. Aktivitas siswa pada penelitian ini secara umum dari seluruh aspek berada pada kategori "efektif", karena semua aspek aktivitas telah mencapai persentase yang ditetapkan.

4. Terdapat perubahan respon siswa dalam menerima materi pembelajaran. Perubahan 
tersebut menggambarkan bahwa siswa merasa senang untuk mengikuti pembelajaran metode eksperimen berbasis KIT IPA untuk materi lain. Respon siswa dapat dinyatakan "positif", karena memenuhi unsur: senang, baru, berminat, dan jelas.

\section{DAFTAR PUSTAKA}

Ibrahim, M. (2005). Asesmen Berkelanjutan. Surabaya: Unesa University Press

Joyce B., Weil M., Calhoun E. (2011). The Model Of Teaching Eighth Edition, terjemahan Fawaid, A., Mirza, A. Yogyakarta: Pustaka Pelajar

Muna, Z. (2014). Pengajaran Pokok Bahasan Pesawat Sederhana dengan Metode Eksperimen pada Siswa Sekolah Dasar di SD Negeri Tayu Wetan 02 kelas V semester 2. ( Tesis Tidak Dipuplikasikan).

Samatowa, Usman. (2006). Bagaimana Membelajarkan IPA di Sekolah Dasar.

Sudjana, Nana. (1989). Cara Belajar Siswa Aktif dan Proses Belajar. Bandung: Sinar baru.

Suliyanah, Novitasari. (2014). Pengaruh Penerapan Model Pengajaran Langsung dengan
Metode Eksperimen Terhadap Hasil Belajar dan Kemampuan Berpikir Kritis Siswa Kelas VII MTs. Jurnal Inovasi Pendidikan Fisika (JIPF), Vol. 03 No. 01. 40-44.

Trisnoherawati, Nanik. (2001). Pengaruh Kit IPA Terhadap Prestasi Belajar Siswa.(online) tersedia:http://www.damandiri.or.id/file/ naniktunpabs babIIPdf[, diakses 4 Februari 2014 pikul 22.45 WIB

Winataputra, Udin S. dkk. (2013). Teori Belajar dan Pembelajaran. Jakarta: Universitas Terbuka 